\title{
O CHOQUE ENTRE DOIS UNIVERSOS DISTINTOS E A GUERRA ENTRE AS FRENTES COLONIAIS E OS “CAYAPÓ” MERIDIONAIS
}

\section{THE CLASH BETWEEN TWO DISTINCT UNIVERSES AND THE WAR BETWEEN THE COLONIAL FRONTS AND THE “CAYAPÓ” MERIDIONAL}

Gabriel Zissi Peres Asnis

(UFU/PPGCS (Mestrando)/GEPAEHI ${ }^{1}$ - gabrielasnis@gmail.com)

\begin{abstract}
RESUMO
O PRESENTE TRABALHO SE DESENVOLVE NO DIÁLOGO ENTRE A ANTROPOLOGIA E A HISTÓRIA NA INTENÇÃO DE CONTRIBUIR PARA A CONSTRUÇÃO DE UMA HISTÓRIA DOS ÍNDIOS DA REGIÃO DO NORTE DE SÃO PAULO, TRIÂNGULO MINEIRO, SUL DE GOIÁS E LESTE DO MATO GROSSO DO SUL A PARTIR DO SÉCULO XVIII. O OBJETIVO PRINCIPAL É ANALISAR COMO SE DEU OS PRIMEIROS CONTATOS ENTRE GRUPOS INDÍGENAS DOS JÊ MERIDIONAIS (CAYAPÓ) E AS FRENTES COLONIAIS ATRAVÉS DE UM PRINCÍPIO PROPOSTO PELO ANTROPÓLOGO MARSHALL SAHLINS, QUAL SEJA: A DE QUE OS CONTATOS SÃO MARCADOS PELA PRÁTICA DA ESTRUTURA, CAMPOS SIMBÓLICOS DE SIGNIFICAÇÃO QUE ORGANIZAM AS EXPERIÊNCIAS, E POR UMA ESTRUTURA DA PRÁTICA NA QUAL, AO SEREM ACIONADOS EM CONTEXTOS PRAGMÁTICOS, OS CAMPOS SIMBÓLICOS SE MODIFICAM AO LONGO DOS ENCONTROS ENTRE ALTERIDADES.
\end{abstract}

\section{ABSTRACT}

THE PRESENT WORK IS DEVELOPED IN THE DIALOGUE BETWEEN ANTHROPOLOGY AND HISTORY IN THE INTENTION TO CONTRIBUTE TO THE CONSTRUCTION OF A HISTORY OF THE INDIANS OF THE REGION OF NORTH OF SÃO PAULO, TRIÂNGULO MINEIRO, SOUTH OF GOIÁS AND EAST OS MATO GROSSO DO SUL FROM THE CENTURY XVIII. THE MAIN OBJECTIVE IS TO ANALYSE HOW WAS THE FIRST CONTACTS BETWEEN INDIGENOUS GROUPS OF "JÊ MERIDIONAIS" (CAYAPÓ) AND THE COLONIAL FRONTS THROUGH A PRINCIPLE PROPOSED BY THE ANTHROPOLOGIST MARSHALL SAHLINS, WHICH IS THAT THE CONTACTS ARE MARKED BY THE PRACTICE OF THE STRUCTURE, FIELDS SYMBOLICS OF SIGNIFICANCE ORGANIZING THE EXPERIENCES, AND A STRUCTURE OF THE PRACTICE IN WHICH, WHEN THEY ARE ACTIONED IN PRAGMATIC CONTEXTS, THE SYMBOLIC FIELDS MODIFY ALONG THE MEETINGS AMONG ALTERATIONS.

PALAVRAS-CHAVE: ANTROPOLOGIA; “CAYAPÓ” MERDIONAL; HISTÓRIA DOS ÍNDIOS.

\footnotetext{
${ }^{1}$ Membro do Grupo de Estudos e Pesquisa em Arqueologia, Etnologia e História Indígena da Universidade Federal de Uberlândia.
} 
KEYWORDS: ANTHROPOLOGY; “CAYAPÓ” MERIDIONAL; HISTORY OF THE INDIANS. INTRODUÇÃO

Para compreender o choque entre diferentes culturas, é necessário entender o contexto prático e simbólico de cada um dos agentes ou sujeitos sociais envolvidos no contato (sujeitos e lógicas culturais e pragmáticas dos não-índios e dos índios). A lógica dos não-índios está atrelada ao universo simbólico religioso e econômico (como também a dos indígenas), visível na documentação histórica analisada. Por terem sido os responsáveis pelas descrições que chegaram até nós, ou seja, por terem construído essa história, acabaram por inventar a cultura dos Jê Meridionais a partir de si próprios e por meio de alegorias. Isso porque, de acordo com Roy Wagner (2010), é através do choque cultural que uma cultura é inventada. O problema em questão é que a alteridade está invisível na documentação, está oculta e escondida atrás dessas alegorias. A visão indígena sobre o contato não foi retratada. Tal motivo se dá pelo fato de que a "história não é igualmente distribuída, porque tê-la é um sinal de poder e autoridade político-religiosa" (SAHLINS, 1990: 74). Para buscar esta outra história encobertada, recorremos ao paradigma indiciário proposto por Carlo Ginzburg (1989). Este paradigma está relacionado ao exame detalhado daquilo que será investigado, no qual, através dos resíduos, os dados acabam por se revelar.

O paradigma indiciário teria surgido na Itália, no final do século XIX, através de diversos artigos de autoria de Giovanni Morelli sobre a análise de quadros antigos que deveriam ser examinados de forma minuciosa para desvendar a qual pintor eles estariam relacionados, bem como sua veracidade ou não, através das unhas, dos lóbulos das orelhas, das formas dos dedos das mãos e dos pés, traços menores não copiados etc. Essa proposta se baseia em "um método interpretativo centrado sobre os resíduos, sobre os dados marginais, considerados reveladores" (GINZBURG, 1989: 149), não galileano, ${ }^{2}$ que permitem capturar uma realidade mais profunda, que de outra forma seria inatingível. São as pistas (sintomas, indícios e signos) que desvendam o todo. Ginzburg associa o paradigma ao trabalho realizado pelo detetive Sherlock Holmes, que desvenda seus casos através dos mínimos detalhes. Freud também aponta que o método de Morelli está estreitamente ligado à técnica da psicanálise médica, visto que essa “também tem por hábito penetrar em coisas concretas e ocultas através

\footnotetext{
2 "O emprego da matemática e o método experimental, de fato, implicavam respectivamente a quantificação e a repetibilidade dos fenômenos, enquanto a perspectiva individualizante excluía por definição a segunda, e admitia a primeira apenas em funções auxiliares" (GINZBURG, 1989: 156). Isso porquê o paradigma indiciário é eminentemente qualitativo e individualizante.
} 
de elementos pouco notados ou desapercebidos, dos detritos ou 'refugos' da nossa observação" (GINZBURG, 1989: 147). Sobre a utilização do paradigma na História, Ginzburg associa, também, o trabalho do historiador ao do médico:

A história se manteve como uma ciência social sui generis, irremediavelmente ligada ao concreto. Mesmo que o historiador não possa deixar de se referir, explícita ou implicitamente, a séries de fenômenos comparáveis, a sua estratégia cognoscitiva assim como os seus códigos expressivos permanecem intrinsecamente individualizantes (mesmo que o indivíduo seja talvez um grupo social ou uma sociedade inteira). Nesse sentido, o historiador é comparável ao médico, que utiliza os quadros nosográficos para analisar o mal específico de cada doente. E, como o do médico, o conhecimento histórico é indireto, indiciário, conjetural. (GINZBURG, 1989: 156-157)

Foi com essa metodologia que Ginzburg trabalhou em uma de suas mais conhecidas obras - O queijo e os vermes (2006) -, em que analisa os documentos da história moderna italiana com o olhar antropológico da alteridade, descrevendo e resgatando a visão de mundo do moleiro Domenico Scandella, mais conhecido como Menocchio, acusado pela Inquisição no século XVI por contrariar a Igreja católica ao afirmar que o mundo tinha origem na putrefação. ${ }^{3}$ Dessa forma, a partir do paradigma indiciário e da perspectiva antropológica da alteridade, abrem-se as vias para as análises da participação dos índios na História.

Nesse sentido, quando, a partir do século XVIII, a história do contato dos Kayapó meridionais os coloca em relação às frentes coloniais, entram em choque duas lógicas culturais distintas em que, cada qual à sua maneira, foi incorporada uma pela outra ao seu campo semântico de explicação. (MANO, 2015: 58-59)

Outro autor utilizado como base na construção dessa nova história indígena dos Jê Meridionais é o antropólogo Marshall Sahlins, que faz uma análise do contato entre a tripulação do capitão James Cook e as sociedades insulares do Havaí, Fiji e Nova Zelândia no século XVIII, mostrando o que foi apontado acima por Marcel Mano, no que se refere a incorporação de duas lógicas culturais distintas em seus campos semânticos de explicação. Segundo sua análise, as diferentes ordens culturais possuem modelos próprios de ação, consciência e determinação histórica e, através da união entre Antropologia e História, é

\footnotetext{
3 "A escassez de testemunhos sobre o comportamento e as atitudes das classes subalternas do passado é com certeza o primeiro - mas não único - obstáculo contra o qual as pesquisas históricas do gênero se chocam. Porém, é uma regra que admite exceções. Este livro conta a história de um moleiro friulano - Domenico Scandella, conhecido por Menocchio - queimado por ordem do Santo Ofício, depois de uma vida transcorrida em total anonimato. A documentação dos dois processos abertos contra ele, distantes quinze anos um do outro, nos dá um quadro rico de suas ideias e sentimentos, fantasias e aspirações. Outros documentos nos fornecem indicações sobre suas atividades econômicas, sobre a vida de seus filhos. Temos também algumas páginas escritas por ele mesmo e uma lista parcial de suas leituras (sabia ler e escrever). Gostaríamos, é claro, de saber muitas outras coisas sobre Menocchio. Mas o que temos em mãos já nos permite reconstruir um fragmento do que se costuma denominar 'cultura subalterna' ou ainda 'cultura popular"' (GINZBURG, 2006: 11).
} 
possível aferir sobre os modelos culturais e históricos, estrutura e evento, signos e interesses. Segundo Lévi-Strauss (1970), o inconsciente seria objeto de estudo do antropólogo, enquanto o consciente do historiador, entretanto, já defendia que os dois procedimentos são indissociáveis e que "seria inexato dizer que, no caminho do conhecimento do homem que vai do estudo dos conteúdos conscientes ao das formas inconscientes, o historiador e o etnólogo caminham em direções inversas: ambos se dirigem no mesmo sentido" (LÉVI-STRAUSS, 1970: 42).

Unindo as duas áreas do conhecimento podemos buscar as motivações indígenas invisíveis nos documentos. Segundo um exemplo de Sahlins: "O peso estrutural que o parentesco real é forçado a suportar ajuda a explicar as intrigas bizantinas, que têm como clímax cenas cruéis de fratricídio ou parricídio, tantas vezes relatadas nos anais da história heroica" (1990: 71-72), ou seja, os mitos ajudam a explicar os eventos, é a cultura ordenando a ação histórica. O parentesco, neste exemplo de Sahlins, possibilita uma compreensão mais abrangente sobre as intrigas familiares no Império Bizantino. Da mesma forma, o entendimento sobre os mitos Kayapó ${ }^{4}$ permite compreender a guerra entre índios e não-índios na região de estudo. Isso está associado a uma relação histórica entre a ordem estrutural e a prática empírica, em uma dialética permanente entre prática da estrutura e estrutura da prática. Entende-se que o campo da estrutura, do inconsciente, está em constante movimentação com o campo da contingência. Assim, como a história dos contatos coloca em ação ao menos duas práticas das estruturas (indígenas e não indígenas), deste choque ambas saem alteradas, pois a cultura e os signos são atualizados na ação histórica.

Marshall Sahlins (2008) acaba por superar tais distinções (campo da contingência e campo da estrutura) ao propor que tanto a estrutura quanto a prática são movediças no momento do contato entre alteridades, como por exemplo, o apontamento do autor sobre as relações comerciais entre havaianos e os marinheiros ingleses, que em um primeiro momento era permitido somente pelo rei havaiano, por se tratar de um tabu, e que passa a se dar entre as pessoas comuns, por interesses próprios, ou seja, ocorre uma violação dos tabus, modificando as estruturas. Se há dialética entre estrutura e história, inconsciente e consciente, já apontados por Marx, Lévi-Strauss, Sartre, Escola dos Anales etc, e visto que a própria história é o campo

\footnotetext{
${ }^{4}$ Ao longo do artigo este termo aparecerá com a letra $\mathrm{C}$ entre aspas: "Cayapó”; como também com a letra $\mathrm{K}$ sem aspas: Kayapó. O primeiro é o seu modo de aparecimento na documentação histórica, e o segundo é a normatização da ABA (Associação Brasileira de Antropologia), sendo o modo de aparecimento na Etnografia.
} 
das possibilidades, ou seja, os sujeitos, os eventos, as relações de contato, os pontos de vista entre outros, são múltiplos, é evidente, que nesta interface, as estruturas, o inconsciente, os campos de significação, também se tornam, por indução, múltiplos. E eis que surge um novo modelo para se pensar a História, uma teoria das multiplicidades por elas mesmas, uma cadeia rizomática.

[...] as multiplicidades ultrapassam a distinção entre a consciência e o inconsciente, entre a natureza e a história, o corpo e a alma. As multiplicidades são a própria realidade, e não supõem nenhuma unidade, não entram em nenhuma totalidade e tampouco remetem a um sujeito. As subjetivações, as totalizações, as unificações são, ao contrário, processos que se produzem e aparecem nas multiplicidades (DELEUZE \& GUATARRI, 2011: 10)

Talvez esta teorização do que foi apresentado se mostre mais clara na análise empírica de descrição sobre o universo simbólico dos Jê Meridionais e suas relações no momento do contato. Tarefa árdua, mas necessária, pois só assim é possível buscar a fundo o contexto prático e simbólico desses grupos indígenas.

\section{UNIVERSO DOS JÊ MERIDIONAIS}

Os contextos simbólicos dos portugueses que criaram as alegorias da colonização, como a representação do "sertão", a distinção entre Tupis e Tapuias, a guerra justa, a catequese e a civilização, inferiram na necessidade dos não-índios de fazer a guerra contra os povos indígenas da região do norte de São Paulo, Triângulo Mineiro, sul de Goiás e leste do Mato Grosso do sul e que embasaram, também, a política indigenista até o Diretório pombalino. Neste tópico nosso interesse é o de mostrar o contexto em que esses grupos indígenas estavam inseridos, sondando suas lógicas culturais e pragmáticas relacionadas, entre outras, ao universo simbólico da guerra. Para isso, iniciamos com uma discussão sobre a mitologia Jê, assim como fez Sahlins (1990; 2008) com os grupos insulares do pacífico, tentando entender como se deu a prática da estrutura e posteriormente a estrutura da prática.

No universo simbólico dos Kayapó, ${ }^{5}$ dois mitos fundadores são importantes para entendermos suas relações com a alteridade e que fazem referência a roubarem e matarem o mundo exterior. O primeiro é o roubo do fogo, recolhido entre os Xikrin-Mebêngôkre, que está associado a apropriação da cultura por parte dos índios que antes viviam no estado de

\footnotetext{
${ }^{5}$ Os mitos utilizados são provenientes de grupos pertencentes aos Kayapó setentrionais, e não meridionais, foco deste artigo. O que nos permite realizar esta projeção etnográfica são as características semelhantes entre os grupos falantes da língua Jê, "como, por exemplo, o dualismo em suas práticas cotidianas na aldeia e em suas relações" (JUNQUEIRA, 2017: 49).
} 
natureza, isso porque, de acordo com o mito, o fogo pertencia à onça, ela comia o alimento cozido enquanto o índio o comia cru.

Antigamente, os índios não tinham fogo, comiam caça seca ao sol e pau puba. Um índio levou o seu cunhado mais novo para pegar filhotes (ou ovos) de arara. Foram e colocaram uma armação de varas até o buraco da arara nas pedras. Aí o mais novo subiu. Não pegou arara porque estava com medo (ou não havia nada ali, ou compadeceu-se com os filhotes), pegou uma pedra e jogou para baixo, acertando a mão do cunhado, que aguardava. Este zangou-se, tirou a vara e foi embora e o menino ficou lá em cima entregue à própria sorte: comia o que defecava, bebia o que urinava. Não tinha nada em cima das pedras. Ele ficou muito magro, quase moribundo. Enquanto isso, um dia, Onça foi caçar, matou um caititu e veio carregando. No caminho, viu a sombra do índio no chão. Em vão, por mais de uma vez, tentou agarrar a sombra, pensando que fosse o rapaz. Até que olhou para cima e viu o índio. Onça chamou-lhe e botou a vara para que descesse. Ele titubeou, mas acabou concordando. Quando ia descendo, pegou um filhote de arara e jogou para a onça comer. Depois a onça o levou nas costas para a casa. Quando chegou lá a mulher de Onça estava fiando algodão. Onça disse: "Eu trouxe um menino". Aí assou carne e deu muito de comer para ele, que estava fraco por ter passado muito tempo nas pedras. O menino chamava a mulher de Onça de nhirua (vocativo para mãe) e Onça de djunua (pai). Onça disse à mulher: "Quando ele ficar com fome, você tira carne e dá". O menino ficou com fome, mas ela não lhe deu comida, aí ele pegou carne e saiu correndo com medo dela, que o ameaçou mostrando as garras. Quando Onça voltou, o índio contou o ocorrido, e aquele lhe fez arco e flecha dizendo: "Se ela te ameaçar de novo, não hesites em matála". Mas a mulher de Onça começou de novo a implicar e não deu carne. O menino a matou. O menino fez um cofo para carregar beiju e Onça, pai dele, mostrou-lhe o rumo de sua aldeia de origem. Ele foi embora levou carne assada e beiju para a aldeia. Andou um dia e chegou. Contou aos outros que tinha acontecido. Disse que lá tinha fogo, que Onça comia assado. Foram todos lá. Pegaram um jatobá grande queimado e carregaram nas costas, todos juntos. E a onça ficou sem fogo até agora. Ela come cru e nós comemos cozido. (GORDON, 2006: 445-446)

Vemos aqui uma inversão de significados, é o mundo exterior que possui o domínio sobre a cultura. Dessa forma, através do roubo, aquilo que estava do outro lado das fronteiras passa a ser propriedade do mundo interior (MANO, 2012), logo, a cultura é apropriada, e os índios passam a alimentar-se do cozido, enquanto a onça come cru. Distingue-se aqui natureza e cultura, mas em sentidos inversos no antes e depois do roubo do fogo. Antes a natureza se dava no interior e a cultura no exterior, posteriormente, ocorre uma alteração na qual a natureza se encontra no externo e a cultura no interno. Os indígenas passam a dominála.

O outro mito fundador faz alusão ao assassinato do inimigo, logo, do mundo externo. O mito, recolhido também entre os Xikrin-Mebêngôkre, na década de 1970, por Lux Vidal (1977: 224-225 apud MANO, 2012: 139), conta como que dois irmãos venceram a luta contra o Grande Gavião. 
Kukryt-Kakô e Kukryt-Uire eram dois meninos de aproximadamente dez anos. O avô estava fazendo flechas; e a avó (kwaty) chamou os meninos para irem tirar palmito. Eles foram. A velha estava cortando palmito debaixo do Grande Gavião. O Gavião já vinha trazendo um homem que tinha pegado enquanto estava caçando. Quando pôs o homem no ninho, ele avistou a velha cortando palmito. Aí, o Gavião desceu, pegou a velha, subiu e botou no ninho. Os meninos ficaram chorando: "E agora?". Os meninos quebram palha, botaram nas costas e foram embora. Chegaram chorando onde o avô estava fazendo as flechas. Ele perguntou: "Cadê a avó?". "O Gavião pegou". O avô disse: "Eu vou matar o Gavião". Mas não matou, foi só olhar. O Gavião estava pousado num jatobá; o avô olhou e voltou chorando. O Gavião estava comendo a velha. Aí ele ficou pensando, à noite, o que iria fazer com o Gavião. No outro dia ele foi procurar um grotão grande. Quando encontrou, levou os meninos e os pôs dentro d'água. Alimentou-os com muita batata, beiju, banana, inhame. [...]. Com cinqüenta dias os pés dos meninos já estavam do outro lado seco (na outra margem), bem para cima. Peixes andavam por cima deles, cobra, poraquê, jacaré. Todo bicho andava por cima deles, e eles ficavam quietos, não se mexiam. O peixe pensava que era pau. Quando o avô viu que os pés estavam do outro lado, do seco, ele foi buscar todo mundo, foi avisar. Ele fez borduna ( $k \hat{o})$, a lança comprida (nojx), buzina pequena de taboca $(\tilde{o}-i)$. Aí todo mundo foi, de manhã cedo, levar urucum, coco, talha de coco para tirar a gosma de peixe dos meninos. [...]. Depois pintaram-nos de urucum. De noite, o avô fez um abrigo de palha ( $k a^{\prime}$ 'ê para matar o Gavião. Às cinco horas da manhã os dois irmãos entraram e esperaram o dia abrir. Ninguém foi com eles. Quando era as dez Kukryt-Uire saiu e chamou de cima, isto várias vezes. Quando o Gavião cansou, botou a língua de fora e ficou com as asas abertas. Os dois irmãos ficaram com medo de matar. O Gavião subiu de novo, depois desceu e, desta vez, eles mataram com a lança, mataram com a borduna, tiraram a penugem e puseram na cabeça como enfeite e ficaram cantando. Chegaram lá para contar ao velho. Todo mundo foi então cortar o Gavião miúdo, miudinho. No mato, tiraram uma pena e saiu um gavião, uma pena menor, saiu um urubu, outra pena, uma arara. Fizeram todas as aves. (VIDAL.1977: 224-225 apud MANO, 2012: 139)

A construção deste mito transformou aqueles que eram fracos e indefesos em corajosos, bravos e guerreiros. Através da violência e da vingança, os Kayapó se tornaram destemidos. Ao cortarem as partes do Gavião e roubarem suas penas, acabaram se apossando de um bem do inimigo como forma de construção de uma identidade. "Trata-se, portanto de um pleno processo de produção do interior pela destruição do exterior. Ao destruírem a ave predadora, produziram o mundo Kayapó” (MANO, 2012: 142).

Assim como nos mitos, na história esses grupos indígenas orientavam suas ações com o mundo exterior não índio utilizando como modelo as façanhas de seus heróis no tempo mítico, "a história era interpretada pelo mito e esse fornecia as ferramentas da ação histórica" (MANO, 2015: 70). "Os crueis assacinios, incendios e roubos, que este barbaro tem commetido são inumeraveis, [...]" (R.IHGB, TOMO 84: 62). ${ }^{6}$ Assim retratadas as ações dos "Cayapó" no decorrer dos documentos históricos, interpreta-se que os não-índios forneceram

\footnotetext{
${ }^{6}$ R.IHGB $=$ Revista do Instituto Histórico e Geográfico Brasileiro.
} 
as chances de atualização do mito fundador como parte de um regime simbólico e relacional (MANO, 2015), onde a guerra, antes inserida em um contexto mitológico, passa para o campo da contingência. É a prática da estrutura. A destruição do inimigo (Gavião ou não-índio) e o roubo figurativo do fogo da onça ou dos bens materiais, ${ }^{7}$ significam tanto a glória Kayapó como a apropriação sobre o outro, o presente passa ser a concretização do passado, eles se encontram na história, as experiências pretéritas representam o presente vivido, e "se o presente reproduz o passado, é porque os habitantes desse mundo são instâncias dos mesmos seres que os procederam" (SAHLINS, 1990: 84). Esta seria, como aponta Sahlins (1990), a justificativa de uma prática histórica através do mito, são metáforas históricas de uma realidade mítica. E se em grande parte da documentação referente aos Kayapó eles são mencionados como sendo violentos, roubando e destruindo tudo por onde passavam, talvez seja porque é desta forma que eles se conectavam com o mundo exterior para reafirmarem suas subjetividades.

Para eles, a guerra não tinha como fim o aniquilamento do outro pelo ódio ou por uma suposta natureza bárbara, como fez pensar a documentação oficial. Antes, as guerras eram oportunidades para a construção de pessoas, corpos e parentes, porque eram nitidamente uma predação do "outro" para a construção do "nós". (MANO, 2015: 70)

Ao que tudo indica, a prática da estrutura da guerra não se colocou apenas nas relações de contato com os não-índios. Parte de uma documentação nos revela que não só estes eram tidos como inimigos, como também os índios pertencentes a outros grupos, como mostra a carta do Governador de Goiás, João Manoel de Mello, de 1760, ao rei de Portugal: “O Gentio Cayapó he o mais barbaro, e indômito de quantos produzio America não só he inimigo irreconciliavel dos Portuguezes, mas de todos os outros Indios" (R.IHGB, TOMO 84: 61). Um exemplo é o do suposto extermínio dos "Gentios" "Goyaz" e Krixá que, fugindo do avanço colonial e deixando suas terras, foram atacados pelos "Cayapó", como mostra a mesma carta: "e se entende que as flechas deste novo Gentio que vinham entrando acabarão os outros que hião sahindo pois não tornou haver notícias d'elles" (R.IHGB, TOMO 84: 61). Um outro exemplo é o dos Araxá, ${ }^{8}$ que segundo Robert Mori (2015), todos os homens teriam

\footnotetext{
7 “O barbaro Gentio Caya-pó assaltou com a sua costumada ferocidade algumas roças d'esta Capitania matando parte dos pretos que as cultivavão, e dois brancos que n'ellas assistião e levando os despojos as reduzirão a cinzas foi tão grande o terror, que cauzou a noticia que todos os mineiros que ficavão em sítios expostos suspenderão a extração do ouro, e com todos os seus escravos estão continuamente com as armas nas mãos para deffenderem as suas cazas" (R.IHGB, TOMO 84: 87).

${ }^{8}$ Os Araxá são um grupo indígena mencionados na documentação do século XVIII e que habitava, também, o "Sertão do Gentio Cayapó", onde hoje se encontra o Triângulo Mineiro.
} 
sido dizimados pelos ataques "Cayapó".9

Essa relação com o mundo exterior pode ser analisada etnologicamente a partir do modelo circular das aldeias Jê do Brasil central, pois como observa Lévi-Strauss (VIVEIROS DE CASTRO, 1996), para os "selvagens", a humanidade cessa nas fronteiras do grupo. O mesmo ocorria na visão portuguesa a respeito do "sertão". Ambos tinham percepções análogas com relação a exterioridade de seus mundos, mas não significa que na prática não se apropriassem dele.

O formato circular das aldeias já aparece na documentação a respeito dos "Cayapó", sendo descritas como sendo "copiosas aldêas em circumferencia de mais de 800 leguas" (D.I, vol.13 anexo I: 283-284). Lévi-Strauss, quando esteve entre os Bororo na primeira metade do século XX, observou que as aldeias circulares "parecem típicas de todas as tribos do grupo linguístico jê que ocupam o planalto central brasileiro" (1996: 233), elegendo-os como um modelo ideal das organizações e do pensamento dualista. "Nesses grupos o formato circular das aldeias e as linhas norte - sul e/ou leste - oeste que cortam o plano circular das mesmas em eixos diametrais têm relação com o universo simbólico e social" (MANO, 2018: 14). Este traçado de linhas no plano diametral estaria relacionado à estrutura de metades exogâmicas representadas totemicamente, possibilitando a circulação de pessoas, serviços, bens e símbolos no universo interior Jê. Tal modelo definiu esses grupos na etnologia como sendo "fechados na espacialidade; centrípetos; de identidade binária; e com uma relação de predação cerimonial da alteridade" (MANO, 2018: 14). Dessa forma, seria possível aferir que por se tratar de um sistema fechado (CARNEIRO DA CUNHA \& VIVEIROS DE CASTRO, 1985; FAUSTO, 2001), o universo Kayapó estaria relacionado a um etnocentrismo em que o externo estaria fora do campo da humanidade, o que justificaria os massacres relatados nos documentos, sem deixarem sobreviventes e, consequentemente, a suposta ausência de reféns, ${ }^{10}$ pois "não havia possibilidade de serem incorporados em seus "SDG' ou 'clãs"” (GIRALDIN, 1997: 50).

Em contrapartida, um outro dualismo inscrito nas aldeias é o das linhas concêntricas,

\footnotetext{
${ }^{9}$ Robert Mori aventa a possibilidade de que os Araxá poderiam ser um grupo pertencente aos Kayapó do Sul em razão de três elementos: a área de ocupação, a forma de ataque e a reciprocidade negativa (morte dos homens e captura das mulheres e crianças. (2015: 207).

10 "matando e roubando aos Viajantes que vão, e vem, e aos roceyros insultandoos em suas próprias cazas, queymando-lhes citios, e os payoys em que tem recolhido os seus fructos matandolhes tambem os seos escravos, cavallos, porcos, e mais criações havendose com tão barbara crueldade, que nem as crianças perdoão, nem dão quartel a pessoa alguma [...]. (D.I., vol.22: 185)
} 
no qual as divergências do círculo central e periférico estão associadas a masculino/feminino, solteiro/casado e sagrado/profano. Porém, diferente do primeiro dualismo apresentado, que segundo Lévi-Strauss (1970) é estático, o dualismo concêntrico apresenta na verdade um triadismo implícito,

A natureza ternária do dualismo concêntrico destaca-se, também, numa outra observação: é um sistema que não se basta em si mesmo e que deve referir-se sempre ao meio que o circunda. A oposição entre terreno limpo (círculo central) e terreno baldio (círculo periférico), apresenta um terceiro termo: mato ou floresta - isto é, terreno virgem - que circunscreve o conjunto binário, mas também o prolonga, já que o terreno limpo está para o baldio como êste está para o terreno virgem. (LÉVISTRAUSS, 1970: 169)

Vendo por este ângulo percebe-se que o sistema fechado desses grupos é ilusório, isso porque, segundo Lévi-Strauss (1970), no sistema diametral, o elemento do terreno virgem, esse triadísmo implícito, não é pertinente, ou, em outras palavras, é menos importante na conjuntura interna social, o que o fez ser "deixado de lado" pela etnologia. Isso acarreta alguns problemas relacionados ao campo estrutural e o campo da contingência, bem como a própria noção de dualismo. Mesmo que na mitologia tais modelos funcionem, o sistema não se fecha quando vistos através dos dados empíricos. Dessa forma, cai em descrédito o modelo centrípeto em que esses grupos foram colocados e em substituição os pensamos como sendo centrípetos e centrífugos (GORDON, 2006; RODRIGUES, 2013), ora mais abertos, ora mais fechados; mais abertos para uns, mais fechados para outros; e assim por diante, em um múltiplo de possibilidades. Interno e externo estavam em contínuo fluxo e não em campos separados.

\section{DADOS EMPÍRICOS E PROBLEMAS ETNOLÓGICOS}

Essa cosmologia ameríndia, em que o centro definiria o ser Kayapó como bravo e guerreiro e o externo ocupado por animais e outros povos, ocasionou uma analogia entre o universo da natureza e o universo dos não-índios e outros índios (MANO, 2018), assim como no mito, onde gavião e onça habitavam o externo e eram inimigos, outros povos, que não Kayapó, também o seriam, daí a associação entre a guerra (predação dos homens) e a caça (predação da natureza) (JUNQUEIRA, 2017). Dessa maneira, segundo aponta Giraldin, aqueles não-índios que estavam adentrando a região de ocupação Kayapó, foram denominados "hi'pe ou kahen, inimigo, o qual pertencia a uma categoria que era definida como hostil e, portanto, deveria ser morta" (1997: 50).

Os problemas que os dados empíricos nos trazem é que nem todos os que habitavam 
fora do universo Kayapó eram tidos como inimigos. E mais, variavam ora como aliados ora como inimigos mortais de acordo com os interesses pragmáticos, ou seja, o exterior abria um leque de possibilidades e não o contrário, como se creditou na etnologia Jê. $\mathrm{O}$ universo externo ao mundo Kayapó seria, estruturalmente falando, o local onde habita o inimigo (gavião, não-índio e outros grupos indígenas), onde se realiza a prática da estrutura. Porém, na história, o "lado de lá" das fronteiras das aldeias é o local onde a prática da estrutura se transforma na estrutura da prática através do contato com os diferentes, assim como o exemplo dado por Lévi-Strauss (1970) sobre o jogo das cartas; as cartas e as regras do jogo são estruturais, mas as possibilidades de combinações das cartas são contingenciais. Ora, se Sahlins defende que a cultura ordena os eventos, mas a recíproca também é verdadeira, entramos então no campo das multiplicidades, afinal, os eventos históricos são múltiplos, os diferentes sujeitos e as relações entre eles também o são. As combinações possíveis entre os diferentes agentes históricos (guerra, aliança, paz, comércio etc), igual o exemplo das cartas, por serem contingenciais, são múltiplos e modificam as estruturas através da dialética entre ambas, ocasionando a formação de um rizoma, tal como proposto por Deleuze \& Guatarri (2011).

Vejamos como exemplo o caso dos mencionados Araxá. Todos os homens teriam sido exterminados, mas de acordo com a documentação, mulheres e crianças foram levadas para o cativeiro: "que não só the fizeram huma grande mortand. ${ }^{\text {de }}$ mas depois lhe cativarão todas as mulheres e crianças, as quais levarão p. ${ }^{a}$ seo alojam. ${ }^{\text {to }}$ p. ${ }^{a}$ as comerem, porque sempre que tem ocasião se sustentão de carne humana". ${ }^{11}$ Primeiramente, a antropofagia não era praticada pelos povos de língua Jê, sendo assim uma construção alegórica do contato, além de que, neste caso, todos os homens foram mortos, impossibilitando o ritual antropofágico. Diante da situação dos cativos, Marcel Mano aponta que,

Como contraponto à interpretação da antropofagia, sugere-se um segundo caminho para explicar o destino dos cativos. Com lastro em descrições de práticas de rapto em diferentes sociedades ameríndias, mesmo culturalmente diferentes entre si, esse novo caminho sugere que as crianças capturadas eram, possivelmente, adotadas e submetidas ao processo de socialização como qualquer outra criança; e as jovens moças, após processo de socialização que devia passar pelo aprendizado da língua, se tornavam casáveis ou, quando não, por meio delas os grupos captores aprendiam cantos, cerimônias e conhecimentos. (2018: 17)

Analogicamente, a relação com não-índios também não se deu somente pela guerra,

\footnotetext{
${ }^{11}$ Carta do governador e capitão-geral de Goiás, conde dos Arcos, D. Marcos de Noronha, ao rei D. José [...]. (24/01/1751). AHU - Caixa: 6, Documento: 465. Apud (MORI, 2015: 81).
} 
mas também através de alianças. Pesquisas mostram que enquanto os "Cayapó" estavam atacando e matando escravos negros nas roças, nos alojamentos e nos caminhos, ${ }^{12}$ também estavam fazendo alianças com negros fugidos da escravidão (ALVES, 2017), mantendo relações com quilombolas e homens livres pobres como auxílio aos seus interesses. A alteridade então não é mais vista em um único sentido, mas sim em vários, com diferentes formas de agenciamento e, dessa forma, o dualismo parece não se sustentar, círculos concêntricos e linhas diametrais passam a dar lugar a um novo modelo, o modelo em forma de mandala, proposto por Marcel Mano, que

expressa a descentralização, enfatiza as interfaces entre os diferentes sujeitos, categorias e contextos envolvidos nas relações de contatos, e enfoca processos de criação/recriação de "entre-lugares", fronteiras culturais porosas onde se cruzam, se sobrepõe, se retraem e se expandem uma multiplicidade de agenciamentos históricos. (MANO, 2018: 20)

Essa construção teórica se torna possível mediante uma nova releitura documental através do paradigma indiciário. Os documentos históricos são imagens de um mundo construído por ideologias daqueles que os escreveram, mas deixam escapar resíduos quase imperceptíveis, dentro de um contexto geral, que nos permitem averiguar essas diversidades de vínculos com a alteridade. Mandala ou rizoma, partem de um princípio de multiplicidade que acaba por não ter "nenhuma relação com o uno como sujeito ou objeto, como realidade natural ou espiritual, como imagens e mundo" (DELEUZE \& GUATARRI, 2011: 23). Os contextos de alteridade e identidade são apresentados nos resíduos da documentação histórica com uma maior complexidade, os cenários das histórias indígenas nem sempre obedecem a critérios estruturais, na verdade, se em um primeiro momento o contato com a alteridade se deu através de ordens estruturais, em um segundo momento (terceiro, quarto, quinto e assim por diante), essas estruturas sofreram modificações. Todos esses contextos, relacionados com as histórias do contato entre índios e não-índios, vão se interligando em uma grande história formada por várias histórias, onde linhas, e não pontos, como se dava nas estruturas, se ligam e desligam, montam e desmontam, abrem e fecham, quebram e reparam; não são lineares, nem circulares, são "linhas de segmentaridade, de estratificação, como dimensões, mas também linha de fuga ou de desterritorialização como dimensão máxima segundo a qual, em seguindo-a, a multiplicidade se metamorfoseia, mudando de natureza" (DELEUZE \&

\footnotetext{
12 “A nação Cayapó continuando sempre no seu corso se aproveitou de huma hora em que a vigia dos Negros de Francisco de Lemos se tinha separado, para dar com tal violencia em 9 que se achavão na roça trabalhando, que no mesmo momento em que o perigo perceberão forão innocentes victimas d'aquelles Barbaros" (R.IHGB, TOMO 84: 96).
} 
GUATARRI, 2011: 43).

Dessa forma, o choque de cosmovisões distintas fez com que as relações entre índios e não-índios fossem diversas. As aldeias poderiam sim fazer parte de uma cosmologia em que esses grupos se encontrassem como sendo fechados, mas na prática, não necessariamente foi isso que ocorreu. Os sistemas de alteridade e identidade se transformam quando colocados frente a frente com novas possibilidades, em outras palavras, com os contatos, eles se adaptam, se modificam e constroem novos paradigmas em um movimento constante que não se encerra, "cada elemento não para de variar e modificar sua distância em relação aos outros" (DELEUZE \& GUATARRI, 2011: 57).

Com o novo olhar que se constrói, partimos para a descrição histórica da guerra, onde poderemos notar as múltiplas vias adotadas pelos agentes. Os dados documentais terão que ser interpretados através dos indícios. As lógicas culturais serão levadas em consideração, mas não estarão presentes em um campo oposto ao da empiria. As políticas indigenistas serão importantes para entendermos os contextos, mas é pela busca das políticas indígenas que seremos movidos.

\section{A GUERRA}

Ainda nas primeiras menções a respeito dos grupos Jê, denominados "Cayapó" nos documentos, não há relatos da necessidade de se fazer guerra, na verdade, nesse primeiro período do contato, são as alegorias que estão sendo construídas, contextualizadas no que se refere à exonímia, guerra justa, catequese etc. Voltando à descrição de Antônio Pires de Campos, quando este está dando notícias sobre os Pareci, ${ }^{13}$ menciona que os "Cayapó" seriam a nação mais temida em todo o "sertão", por serem astutos e traidores, no qual bastaria "um só caiapó para destruir uma tropa de quinhentas armas de fogo, sendo em qualquer deles usual correr tanto como um cavalo" (CAMPOS, 1976: 195). É explícito um certo exagero quando o sertanista coloca que somente um "Cayapó" seria suficiente para destruir um exército, mas enaltece o lado guerreiro dessa nação, como também deixa um "recado" para a capitania de São Paulo de que um grande contingente de soldados seria necessário para se fazer guerra àquele povo.

\footnotetext{
${ }^{13}$ O termo foi registrado pela primeira vez nessa notícia de Antônio Pires de Campos, na segunda década do século XVIII. Foi aplicado a uma variedade de grupos falantes da língua Aruak e o termo de autodenominação é Halíti, que pode ser traduzido como "gente", referindo-se ao gênero humano em oposição ao mundo animal, quanto como "povo", indicando uma identidade. (https://pib.socioambiental.org/pt/Povo:Paresí acessado em 06/06/2018).
} 
Outro ponto interessante é sobre o "correr tanto como um cavalo". Utilizando da projeção etnográfica, vemos que os Jê, no caso os Timbira, parentes dos Kayapó do Sul (NIMUNEDAJÚ, 2001: 151), bem como esses mesmos Kayapó (POHL, 1951; APARÍCIO, 1988 apud CANCELIER DIAS, 2017), praticam e praticavam a chamada "corrida das toras". Entre os Timbira, trata-se de um ritual matrimonial, em que o jovem rapaz que quer casar-se deve "carregar em passo acelerado uma pesada tora, percorrendo uma determinada distância. Caso não consiga isto, não estará apto para o casamento" (NIMUNDAJÚ, 2001: 152). De acordo com Pohl, a cerimônia entre os Kayapó do Sul, ocorria na festa dos mortos e segundo o governador da Capitania de Goiás, Luis da Cunha Menezes: “[...] no lançar da flecha e em carregar um grande tronco de uma árvore, levando-o mais longe. Com estes e outros exercícios, são tão fortes corredores [...]" (APARÍCIO, 1988: 376 apud CANCELIER DIAS, 2017: 249). ${ }^{14}$ Veja, se um dos seus principais eventos cerimoniais é o da corrida com toras, tal passagem de Antônio Pires de Campos sobre a velocidade em que esses grupos corriam, têm suas explicações, possibilitando entender o lado indígena nessas descrições.

Em viagem até Cuiabá, no ano de 1727, o capitão João Antônio Cabral Camello dá notícias sobre a presença de grandes contingentes de índios "Cayapó". A primeira notícia se dá na região em que o rio Verde entra no rio Grande, local em que se pede cuidado às tropas por afirmarem que ali os "Cayapó" andam sempre em corso. No rio Pardo esses grupos costumam caminhar por toda sua extensão e de acordo com João Antônio Cabral, ao falar sobre dois roceiros de nomes Luiz Rodrigues Vilares e Gregorio de Crasto, o capitão diz que:

Esses dois pobres roceiros vivem como em um presidio, com as armas sempre nas mãos; para irem buscar agua, não obstante o terem-na perto, vão sempre com guardas: no roçar, plantar e colher os mantimentos levam sempre todas as armas, e em quanto vigiam uns, trabalham outros, mas sempre com as espingardas á mão; e nem com toda esta cautela se livram de que em varias occasiões lhe tenham os Cayapó morto á alguns. (J.IHGB, TOMO 4: 491)

Ao entrar no rio Camapuã, novamente os "Cayapó" são mencionados como sendo o maior perigo desse rio, realizando ataques estratégicos, como o citado no documento, em que colocavam fogo nos campos para cercar o inimigo, a fim de impedir sua fuga. Por fim, no atual estado de Mato Grosso do Sul, o rio Taquari é o último rio no qual os "Cayapó" são vistos, de acordo com João Antônio Cabral, “até aqui chegam os Cayapós” (R.IHGB, TOMO 4: 493). Deste ponto em diante os grupos mencionados são os Paiaguá e Guaicurú, como

\footnotetext{
${ }^{14}$ Carta de Luis da Cunha Meneses a Tristão da Cunha Meneses fazendo uma descrição etnográfica dos índios Kayapó e Karajá.
} 
mostra o mapa 2.

Assim sendo, os confrontos que levariam à guerra foram iniciados após a descoberta da serra Dourada pelos bandeirantes, que encontrando vasta gama de ouro, continuaram suas andanças em busca de se deparem com mais, entrando em conflito com os "Cayapó" e expulsando-os de seu alojamento. Segundo Machado de Oliveira (1861), os “Cayapó” teriam fugido para as redondezas da serra de Santa Marta (local que ainda conserva o nome de “sertão dos Cayapó”), próximo ao rio Paraná, estando seguros dos ataques.

Esses indios, acoutados em esconderijos de que podiam evadir-se ao primeiro signal, fosse este da approximação das caravanas e viandantes, ou fosse de perigo para elles, assaltavam os caminhos que de outras capitanias iam ter a Goyaz, assassinavam horrivelmente as comitivas e viageiros sem poupança de sexo ou idade, e apoderavamse dos objectos que só podiam servir para o seu uso, queimando ou inutilisando tudo quanto lhes não convinha" (OLIVEIRA, 1861, p. 503)

De acordo com o historiador, tais atrocidades estariam ocorrendo por vingança às matanças que vinham sofrendo. Mas como vimos, não se tratava somente de vingança, pois dessa forma, cria-se um ar romantizado desses grupos, típico da segunda metade do século XIX. Esses ataques por parte dos "Cayapó" também estavam inseridos nos contextos simbólicos que apresentamos anteriormente. Não se refere somente a um misto de ataque e contra-ataque. As motivações são como um iceberg, somente a menor ponta nos é mostrada, a realidade é muito maior e profunda.

Não só os "Cayapó" eram tidos como empecilho no caminho para as minas, os Paiaguá e os Guaicurú (nação de cavaleiros) também são constantemente mencionados na documentação, inclusive na notícia de Antônio Pires de Campos em 1723. São grupos guerreiros que faziam guerra tanto por terra (Guaicurú), quanto por água (Paiaguá), aterrorizando a vida dos não-índios que estavam se deslocando para Cuiabá e construindo seus assentamentos. É em virtude desses ataques que em maio de 1730 Antônio da Silva Caldeira Pimentel permite a guerra contra todas as nações de "gentio" que cercavam o rio Grande e, em 1732 e 1733 o Conde de Sarzedas (Antônio Luís de Távora) manda fazer guerra contra todas as nações que infestam o caminho das minas, permitindo sua escravidão caso fossem capturados pelas pessoas que lutassem contra eles, de acordo com a lei de 10 de setembro de 1611 (D.I., vol.3: 70-79).

Faço saber [...], as mortes e roubos, que tem feito os Gentios Barbaros, que com elles se confederarão, digo que infestão as dittas Minas, e seo caminho, principal. ${ }^{\text {te }}$ os Indios da nasção Payaguáz, e os mais bárbaros, que com elles se confererarão p. ${ }^{a}$ 
atacarem a tropa, que das d. ${ }^{\text {as }}$ Minas do Cuyabá vinha ao povoado, no anno de mil, e settecentes, e trinta, deque era cabo o D. ${ }^{\text {or }}$ Antonio Alz' Lanhas Peixoto, Ouv. ${ }^{\text {or }}$ dellas, ao qual matarão, e a cento, e tantas pessoas; roubando todo o ouro, que trazião, de que tirando-se devassa, e remetendo-se a S. Mag. ${ }^{\mathrm{e}}$ foy servido ordenar-me por provisão de cinco de Março dimil, e settecentos, e trinta, e dous, e resolução sua do primr. ${ }^{\circ}$ do d. ${ }^{\circ}$ mez, e Anno, por consulta do Conc. ${ }^{\circ}$ Ultramr. ${ }^{\circ}$, mande atacar dentro dos seus alojamentos, assim os d. ${ }^{\text {os }}$ Gentios Payaguás, como tambem as mais nasçoes, que confederadas com elles os ajudassem a nos hostilizar, queimando-lhes, e distuindolhes todas as suas Aldeyas, para que este exemplo, digo, este espetaculo lhes sirva de mayor horror; ficando em cativeiro todos aquelles, que se puderem render, e captivar. (D.I., vol.13 ANEXO F: 242)

Entretanto, como evidenciado na passagem acima, ainda não seriam os "Cayapó" o foco principal dessa guerra, e segundo as ordens do Conde de Sarzedas, "se deve rezervar a guerra se lhe ha de fazer p. ${ }^{\text {a }}$ o fim, castigandoce em primeiro lugar os Payaguases" (D.I., vol.13 ANEXO F: 250). Somente após a destruição deste "gentio", é que seria avaliada a possibilidade, ou não, de combater os "Cayapó": "Em o Comand. te ou quem ocupar o seu lugar acabando de destruhir aos Gentios a que vay dar guerra deve ajustar com os off. ${ }^{\text {es }}$ da tropa, e mais pessoas capazes de voto se hé conveniente vir dar guerra ao Gentio Cayapó" (D.I., vol.13 ANEXO F: 255), sendo essa, a primeira menção encontrada nos documentos analisados sobre a necessidade de se realizar a guerra exclusivamente contra esse grupo em questão.

Após a investida contra os indígenas em 1733 produzir poucos resultados, continuam as queixas dos viajantes, roceiros e moradores sobre as hostilidades e estragos causados principalmente pelos "Cayapó". Dessa forma, os "gentios" continuaram "a infestar os caminhos de Cuyabá, tanto pelos rios como por terra" (D.I., vol.13 ANEXO F: 261). Em consequência desses contínuos ataques e do insucesso da capitania em combatê-los, em 1736, atendendo os pedidos dos não-índios de utilizarem de seus próprios meios para se defender, o Conde de Sarzedas autoriza, por meio de uma Portaria, tal prática, deixando claro ' q'. pessoa algua lhe não ponha impedim. ${ }^{\text {to }}$ antes lhe dem toda ajuda e favor q'. lhe for pedido . $^{\text {a }}$ com mais facilidade se conseguir o dezejado" (D.I., vol.22: 121). Essas e outras tentativas de combate, muito bem apresentadas por Robert Mori (2015: 31-33), continuaram não surtindo o efeito desejado.

Em virtude da situação, em 1739, o capitão-geral Dom Luís Mascarenhas convoca Angelo Preto "para vir de Cuyabá a frente dos seus numerosos Bororós fazer a guerra aos Payaguás” (D.I., vol.13 ANEXO F: 259). Segundo Mori (2015), Angelo Preto, 
deve ter subjugado os Bororo que atacavam a região das minas de Cuiabá, pois, no início do ano de 1727, Rodrigo Cesar de Menezes emitiu uma Ordem ao sertanista e demais sócios, para combater os gentios dos Morrros, e caso os índios resistissem, deveriam ser mortos e os sobreviventes repartidos após a retirada do quinto pertencente ao rei; caso os índios não oferecessem resistência, "ficarão admenistrados do d. ${ }^{\circ}$ Capittão [Angelo Preto] e seus companheiros" (MORI, 2015: 34).

A chegada do sertanista em Vila Boa estava prevista para depois da Páscoa de 1742. Porém, devido a novos ataques dos "Cayapó", uma nova junta foi criada em novembro de 1740, no qual a população manifestou com súplica alguma ação efetiva contra os índios. A solução encontrada por Dom Luís Mascarenhas foi a de "levantar duas Comp. as para desenfestar as campanhas dos suburbios desta Villa do Gentio barbaro Cayapó, que tantas mortes, e estragos continuamente está fazendo" (D.I., vol.22: 166). Em um Bando datado de 27 de dezembro de 1741, Mascarenhas informa que as duas companhias de soldados deveriam ser formadas pelos carijós ${ }^{15}$ e negros forros por não trabalharem e andarem vadiando.

Em 6 de janeiro de 1742, é feito um Regimento com seis itens dando instruções para esses soldados de como agir na investida contra os "Cayapó". O primeiro é uma ordem ao capitão Antônio de Lemos e Faria ${ }^{16}$ de explorar desde a bocaina da Serra Dourada, passando uma nascente até além do sítio de um tal João Rodrigues, examinando todas as pistas ou rastros do "gentio"; o segundo e terceiro, referem-se a táticas de ataque, em que, caso os índios se rendam, deverão ser enviados para uma prisão em Vila Boa, para ser determinado o que se fará com eles, mas caso ocorra o contrário, a ordem é de que passem a "espada sem distinção ou differença algûa de sexo, só não executarão a d. ${ }^{a}$ pena de morte nos meninos ou meninas de des annos p. ${ }^{a}$ baixo, porque estes os conduzirão a esta V. ${ }^{a}$ para deles se tirar o

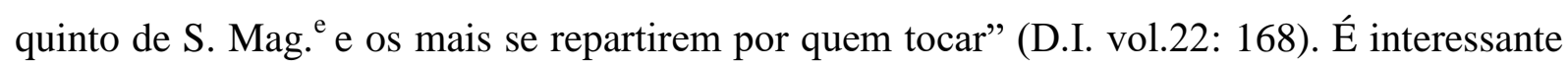
se atentar na nota de rodapé deste documento que diz:

Era a consagração da barbaridade portugueza na conquista do Brazil! É difficil saber quem era mais barbaro, si o índio Cayapó ou o portuguez catholico! E o rei fidelissimo ainda tinha um quinto do producto da venda das crianças indígenas, emquanto as mãis

\footnotetext{
15 “O termo carijó foi utilizado a partir de meados do século XVI para designar as levas de índios guarani escravizados que chegavam à capitania de São Paulo, sendo que após 1640, com a resistência indígena e jesuítica, os paulistas passaram a escravizar índios de diversas origens, o que resultou na utilização do termo carijó a todos os índios subordinados. Já os bastardos, assim como os mamelucos, indicavam os filhos de pais brancos e mães índias, sendo que a diferença entre os primeiros e segundos, residia no fato que estes possuíam o reconhecimento paterno, aproximando-se da identidade portuguesa, enquanto os bastardos seguiam vinculados à sua origem materna, indígena. No século XVIII, bastardo passou a designar qualquer indivíduo que tivesse descendência indígena" (MONTEIRO, 1994 apud MORI, 2015: 35)

${ }^{16}$ Segundo Robert Mori (2015: 37), a Companhia de Soldados, comandada Antônio de Lemos e Faria, chegou a atacar, provavelmente, um grupo "Cayapó" que se deslocava para alguma expedição guerreira (com a justificativa de que estariam indo em direção a Goiás para efetuar hostilidades).
} 
eram trucidadas! (D.I. vol.22: 168)

Tal passagem nos faz lembrar da citação de Lévi-Strauss que diz: "O bárbaro é inicialmente o homem que acredita na barbárie" (1993: 335), ou seja, as imagens que as alegorias da colonização estabeleceram para os grupos indígenas, é o espelho dos próprios construtores dessas imagens, suas ações eram iguais ou piores daquelas que eles próprios diziam confrontar, principalmente por serem eles, os verdadeiros invasores; o quarto tratava do destino dos objetos de valor encontrados nas aldeias atacadas; o quinto sobre a hierarquia, na qual os soldados deveriam obedecer inviolavelmente aos mandatos dos seus capitães; e o sexto proibia o capitão e sua companhia de dormirem mais de uma noite em um mesmo sítio.

Passado algum tempo de espera, Angelo Preto recusa a incumbência de fazer guerra contra os "gentios", sendo decidido, pelo governador da capitania de São Paulo, convocar o sertanista Antônio Pires de Campos, aquele que pela primeira vez utilizou o termo "Cayapó" para descrever diversos grupos indígenas que habitavam as redondezas do rio Paranaíba em 1723.

Aos doze dias do mez de Outubro de 1742, nesta Villa Boa de Goyaz e casa de residencia do Illmo. e Exmo. Sr. general D. Luiz de Mascarenhas, onde eu Manoel Pedro de Macedo Ribeiro, secretario do Governo fui vindo, e ahi estando presente o coronel Antonio Pires de Campos, por elle foi dito que em satisfação do termo da junta retro (2), de dés do dito mez e anno, se obrigava a explorar as campanhas que decorrem da serra Dourada para a parte do Sul até o Rio Grande, e de nenhuma sorte entrar nas campanhas cujas contravertentes decahen para a parte do Norte, em que se incluem o Rio-Claro, Pilões e corrego Santo Antonio, porem sendo caso que em alguma occasião de choque com o gentio que infesta as vizinhanças desta villa, necessite de o seguir para as ditas partes, lhe não servirá de obstaculo o impedimento dos ditos rio, e acontecendo que o gentio que sobre os mesmos rios assiste faça alguma invasão para as vizinhanças desta villa, procurará rechassal-os até os seus alojamentos. (D.I., vol.13 ANEXO F: 259-60)

Celebrando o acordo com Dom Luís Mascarenhas e recebendo uma recompensa de uma arroba de ouro, Antônio Pires de Campos, junto com seus Bororo ${ }^{17}$ e outros "índios mansos", vai se tornar uma das figuras mais importantes para o domínio do "sertão" entre os rios Grande e Paranaíba, sendo responsável pela construção dos primeiros aldeamentos na região, bem como ser reconhecido entre os paulistas como "caçador de índios". E a partir daquele contrato, “os Cayapó eram agora os inimigos” (D.I., vol.13 ANEXO F: 262).

\footnotetext{
17 “o etnônimo 'Bororo' acabou por se tornar comum nos documentos setecentistas que tratavam dos índios dos aldeamentos entre os Rios Grande e Paranaíba, sem menção a indígenas de outros grupos, levando-nos a crer que esse etnônimo foi utilizado como um termo generalizante para os índios que compunham a força guerreira de Pires de Campos. No século XIX, o etnônimo 'Bororo' foi utilizado pelos viajantes europeus também como um termo para designar os índios aldeados no Sertão da Farinha Podre” (MORI, 2015: 71).
} 


\section{ANTÔNIO PIRES DE CAMPOS: O NOME DA GUERRA}

Descendente de uma família de sertanistas, era filho do também chamado Antônio Pires de Campos, natural de Itu e um dos primeiros descobridores dos "sertões" de Minas Gerais, junto com Bartolomeu Bueno da Silva, em 1682. O coronel Antônio Pires de Campos, filho do precedente, é relatado na documentação como sendo um audaz sertanista, que acompanhou o pai em suas explorações e descobertas. Em uma dessas empreitadas, no ano de 1718, descobriu os rios Cuiabá e o afluente Cochipó, na região do atual Mato Grosso, combatendo e conquistando os índios Bororo, levando-os para São Paulo.

Em 1741 fundou o aldeamento de Santa Ana, ${ }^{18}$ no atual Triângulo Mineiro, MG, onde reuniu a tribo dos Bororo e que seriam utilizados na luta contra os "Cayapó”. Segundo Mori,

Os Bororo já eram admirados pelos bandeirantes e sertanistas que se dirigiam para a região de Mato Grosso devido ao seu vigor na luta contra os inimigos. Como hábeis guerreiros, utilizavam de maneira eficiente na guerra, inúmeras técnicas de combate, como cercos e emboscadas (ZAGO, 2005). Eram os combatentes ideais para a guerra contra outros índios. (2015: 37)

No final de 1742, após o acordo com Dom Luís de Mascarenhas, Antônio Pires de Campos, junto com $120^{19}$ Bororo retirados de Cuiabá e levados até Goiás, iniciam uma campanha de guerra contra os "Cayapó". Esse primeiro ataque, realizado nas proximidades do rio Claro, resultou na "destruição da aldeia e a morte de cerca de 16 e o aprisionamento de mais 32 Cayapó" (GIRALDIN, 1994: 74). Até o momento, essa teria sido a maior investida contra os grupos "Cayapó" finalizada com sucesso. Tal êxito foi relacionado na documentação pelo motivo de que Bororos e "Cayapós" seriam historicamente inimigos, entretanto, alguns documentos do final do século XVIII, os colocam como aliados contra os não-índios na região de Cuiabá (RODRIGUES, 2013). Isso é importante para pensarmos como as relações de contato com os não-índios modificam sensivelmente o quadro das alianças e guerras entre índios. Além disso, não seria simplesmente o fato de serem inimigos que levaria os Bororo a acompanhar Pires de Campos. Jogos de interesse nessa aliança? Estratégias de Antônio Pires de Campos? Essas perguntas e muitas outras inserem-se no que foi discutido anteriormente sobre os Jê Meridionais serem considerados grupos fechados. Os

\footnotetext{
${ }^{18}$ Mais informações sobre os aldeamentos destinados a abrigar grupos indígenas utilizados na guerra contra os "Cayapó", ver (MORI, 2015; RAVAGNANI, 1996).

19 Alguns autores (MENDONÇA, 1974; RODRIGUES, 2013), falam de um número de 500 "índios mansos", entre eles, Bororo, Carajás, Parecis, Javaés e Tapirapés.
} 
Bororo, também pertencentes à família linguística Jê, demonstram sua abertura com relação ao universo externo a partir de seus próprios agenciamentos, em um jogo de interesses subjetivos e objetivos.

No dia 15 de outubro de 1742, Dom Luís de Mascarenhas informa sobre a necessidade de se enviar mais homens para Antônio Pires de Campos na luta contra os "Cayapó", segundo a instrução direcionada ao ouvidor geral Manoel Antunes da Fonseca,

Succedendo q.' o Cor. ${ }^{\text {el }}$ da Conquista do Cayapó Antonio Pires de Campos q.' hora anda no sertão em serviço de El Rey, e destes Povos se encontre com algû corpo de Gentio Guerreyro tão numerozo e forte q.' p. ${ }^{a}$ o vencer necessite de ajuda de algûas armas nossas enformandose Vm. primr. ${ }^{\circ}$ exactamente de tudo e achando ser conveniente darlhe a dita ajuda, poderá Vm. formar hûa comp. ${ }^{a}$ de vinte, até trinta Soldados bastardos q.' serão alistados na Vedoria, ou Provedoria da fazenda, pela qual serão preparados, e pagos de seus e mantimentos na forma que com os mesmos se praticou já antes de chegar o dito Coronel com os seus Bororós a esta Villa, cujos soldados serão subgeitos ao mesmo Cor. ${ }^{\mathrm{el}}$ para os comandar com a jurisdição, e na forma q.' dispoem o Regimento militar, e dos ditoz Soldados poderá o referido Cor. ${ }^{\text {el }}$

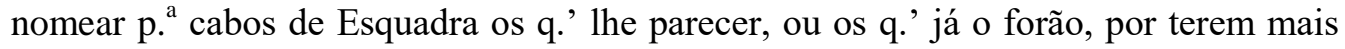
algûa disciplina da guerra do certão, e em se recolhendo da accção a q.' forem enviados se lhe dará baixa por não ficar continuando sem necessidade a despeza da faz. ${ }^{a}$ R. ${ }^{1}$ e ao Prov. ${ }^{\text {or }}$ della fica ordem p. $^{\text {a }}$ toda a despeza referida no cazo figurado. (D.I., vol.22: 175-176)

Nos anos que se seguiram, essas medidas de combate foram se mostrando pouco eficientes, tanto o é que em 1744, os "Cayapó" realizam um ataque ao sítio do Lanhoso, ${ }^{20}$ causando sua total destruição. Um ano depois, após os representantes da Coroa cogitarem novamente os trabalhos de Antônio Pires de Campos e seus índios mestiços, este retorna para Goiás e em 1746 viaja para Cuiabá. Nesse mesmo ano, no dia 8 de maio, o rei Dom João V expediu um Regimento dando ordem real para que o sertanista desinfestasse o caminho das minas e suas vizinhanças dos insultos que o "gentio Cayapó" nelas cometem "para a conservação das pessoas, e bens dos vaçallos do d. ${ }^{\circ}$ Snr." (D.I., vol.22: 210). Para a concretização de tal medida, o Regimento continha 8 itens (D.I., vol.22: 210-213). O primeiro ordenava que o Coronel se estabelecesse com seus guerreiros (Bororo, Pareci e mestiços), no rio das Pedras, entre os rios Grande e Paranaíba, onde seria construído o primeiro aldeamento $^{21}$ (Rio das Pedras) no "Sertão do Gentio Cayapó". O local teria sido escolhido

\footnotetext{
20 “O sítio do Lanhoso estava situado em território da atual cidade de Uberaba (MG), às margens de um córrego homônimo. Posteriormente, no local foi edificado um dos aldeamentos indígenas localizados no Sertão da Farinha Podre" (MORI, 2015: 39).

${ }^{21}$ Segundo Oswaldo Ravagnani (1989), não seria exatamente um aldeamento e sim um quartel-aldeamento, visto que os grupos que lá foram alocados tinham como missão combater os ataques dos "Cayapó" no caminho das minas.
} 


\section{Nanduty}

pelos próprios Bororo, pois possivelmente, já teriam conhecimento da região (MORI, 2015), demonstrando o agenciamento desses grupos e suas próprias práticas históricas. O segundo dizia que os Bororo deveriam andar sempre armados, explorando as estradas, fazendo paragens nos locais em que os "Cayapó" costumavam insultar os viajantes e roceiros, a fim de intimidá-los e evitar suas hostilidades. O terceiro obrigava a construção de outro quartelaldeamento na paragem do Lanhoso, caso o número de Bororos crescesse. O quarto menciona que caso houvesse algum ataque, o coronel seria obrigado a castiga-los e, se o "gentio Cayapó" estivesse em número muito superior ao dos guerreiros de Antônio Pires de Campos, seriam enviados 20 ou 30 "aventureiros" para ajudá-lo.

A partir do quinto item, são apresentadas as promessas caso Pires de Campos saísse vitorioso de suas ações. O número 5 diz que passado um ano sem notícias de novos ataques

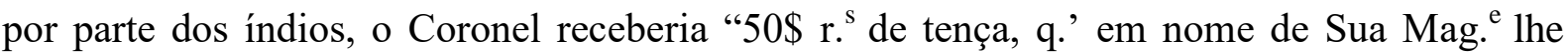
prometto" (D.I., vol.22: 211-212). O sexto item promete o ofício de escrivão da Ouvidoria de Vila Boa, isento de donativo e terças partes, caso se passem três anos sem ataques dos "Cayapó". O sétimo deixa claro que tais promessas só serão cumpridas se, caso ocorra um novo ataque, os índios sejam imediatamente castigados e reduzidos a quietação. O oitavo oferece passagem gratuita para Antônio Pires de Campos, seus cavalos, cargas e mais gente que o acompanhar pelos rios do caminho das minas e pela estrada de Goiás.

No dia 15 de julho de 1748 o Regimento foi assinado entre Antônio Pires de Campos e Dom Luís de Mascarenhas, na Vila de Santos, atual cidade de Santos - SP. 'O q.' tudo o d. ${ }^{o}$ Coronel cumprirá na forma sobre d. ${ }^{a}$ p. ${ }^{a}$ merecer as m. ${ }^{\text {ces }}$ q.' S. Mag. ${ }^{e}$ lhe faz, e me dará conta dos progressos desta dellig. ${ }^{\text {cia }}$, q.' m. $^{\text {to }}$ lhe encarrego como tanto do agrado, e interesse de Sua Mag. e e do publico" (D.I., vol.22: 213). Porém, um mês após o acordo de ambas as partes, Dom Luís de Mascarenhas deixa o posto de governador em virtude da anexação da capitania de São Paulo à capitania do Rio de Janeiro, governado por Gomes Freire de Andrade, que não resgatou a palavra de seu antecessor. Nem mesmo o novo governador da capitania de Goiás que se desmembrou de São Paulo -, Dom Marcos de Noronha, que até 1751, ano da morte de Pires de Campos, se utilizou dos serviços do sertanista, cumpre o trato entre este e Mascarenhas. "A ingratidão foi a paga dos seus grandes serviços ao governo colonial” (D.I., vol.22: 213$)$

Mesmo não sendo gratificado com as promessas que lhe foram feitas, continuou sua 
investida contra os "Cayapó". Em um encontro entre Gomes Freire de Andrade e Dom Marcos de Noronha, o primeiro informa que a estrada de São Paulo até Goiás está desinfestada graças ao coronel Antônio Pires de Campos, que se estabeleceu juto de seus Bororo no meio do caminho entre as regiões (RAVAGNANI, 1996). Entretanto, em 1751, os "Cayapó” invadem Vila Boa, causando a morte de não-índios. Tal acontecimento fez com que Dom Marcos recorresse novamente a Pires de Campos, que partiu com seus guerreiros, mas acabou ferido por uma flecha no peito, sendo obrigado a voltar para Vila Boa. Pouco tempo depois, em uma viagem para Ouro Preto, escoltando uma remessa de ouro, acabou falecendo de febre, na cidade de Paracatú, supostamente causada pelo ferimento ocasionado pela flechada que recebeu em combate contra os "Cayapo" (D.I., vol.22; RAGANANI, 1996). Porém, Robert Mori se atenta e nos mostra que o real motivo da morte do sertanista foi causado pela malária "bastante comum no período colonial, sendo responsável por grandes epidemias, principalmente em áreas que estavam localizadas próximas aos rios e de ocupação recente pelos não-índios" (MORI, 2015, p. 99).

"No período de cinco anos, entre 1746 e 1751, Antônio Pires de Campos será o pivô dos conflitos com os Cayapó. A estratégia era transferir um determinado número de índios Bororo, aldeando-os dentro do território Cayapó" (GIRALDIN, 1994: 78). Foi dessa forma que o sertanista foi considerado "herói da civilização" e até mesmo "cacique" para os Bororo, pois os havia "amansado, aldeiado e armado" (D.I., vol.22: 175). Foi também considerado

açoute do barbaro gentio Cayapó, que infestava a estrada toda de Goyazes em comprimento de mais de 200 leguas desde o rio Uruçanga até Villa-Boa. Impedida por estes barbaros a dita estrada com total ruina do comercio e dos direitos reaes, depois de terem conseguido em repetidos assaltos muitas mortes com horror da humanidade. (D.I., vol 13 ANEXO I: 282)

Tais ações fizeram de Antônio Pires de Campos um sujeito de grande importância para os interesses coloniais. Toda essa construção heroica a respeito dele desconsiderou suas ações, que se mostravam tão mais violentas e, em um certo sentido, "bárbaras", do que a dos índios. Tanto o interesse do sertanista, quanto o das capitanias a que serviu, se referem a propósitos econômicos no domínio da região descrita.

As medidas tomadas por particulares ou as oficiais tinham por objetivo matar os Kayapó. Seus ataques atrapalhavam a coleta e o escoamento do ouro. E suas terras poderiam conter minas auríferas. Enfim, sua presença contrariava os interesses econômicos do capitalismo reinante. (RAVAGNANI, 1996: 230) 
A criação de imagens alegóricas a respeito dos "Cayapó", Paiaguá, Guaicurú, entre outros, e o heroísmo dos agentes coloniais, reflete ainda no imaginário dos dias de hoje. Esses não-índios estavam invadindo territórios que pertenciam a outros grupos e tais grupos os defenderam e também realizaram suas ações em prol de seus interesses. Não há uma dicotomia entre bem e mal; índios bravos e índios mansos; heróis e vilões, todos agiram de acordo com os universos simbólicos a que pertenciam, todos eram mais ou menos um e outro, dependendo apenas do olhar de quem estava observando, todos eram rizomáticos de acordo com as necessidades e campos simbólicos. ${ }^{22}$

O único problema é não termos relatos por parte dos indígenas sobre suas próprias visões e versões a respeito dessa guerra. $\mathrm{O}$ que temos são indícios dos quais nos permitem "enxergar" de outra maneira essa história.

\section{FONTES HISTÓRICAS}

CAMPOS, Antonio Pires de. Breve notícia do gentio bárbaro que há na derrota das minas de Cuiabá e seu recôncavo, na qual declara-se os reinos [...]. In: TAUNAY, Afonso d'E. (org). Relatos Sertanistas. $2^{a}$ ed. São Paulo: Livraria Martins Editora, 1976.

Documentos Interessantes para a história e costumes de São Paulo. Diversos. São Paulo: Typographia Cardozo Filho \& C., Volume 3, 1913.

Documentos Interessantes para a história e costumes de São Paulo. Bandos e Portarias de Rodrigo Cesar de Menezes. São Paulo: Typographia Aurora, Volume 13 Anexos I e F, 1895.

Documentos Interessantes para a história e costumes de São Paulo. Bandos, Regimentos e Ordens dos capitães-generaes Conde de Sarzedas e D. Luis Marcarenhas - 1732-1748. São Paulo: Typographia da Companhia Industrial de São Paulo, Volume 22, 1896.

POHL, Johann Emanuel. Viagem no interior do Brasil: empreendida nos anos de 1817 a 1821 e publicada por ordem de sua majestade o imperador da Áustria Francisco Primeiro. Rio de Janeiro: INL, 1951, vol.1.

Revista do Instituto Histórico e Geográfico Brasileiro. OLIVERIA, Machado de. Os Cayapó: Sua origem; descobrimento; acommettimentos pelos Mamelucos; represalia; meios empregados com violencia, e com arma em punho para subtrahil-os ás mattas; esses meios

\footnotetext{
${ }^{22}$ Neste subtítulo foi apresentado um pouco da história de Antônio Pires de Campos. Nosso interesse foi o de mostrar em que circunstâncias suas ações se deram e como sua imagem foi criada pelos não-índios. Em virtude disso, percebe-se que os "Cayapó" são cognominados a todo o momento como sendo "bárbaros", "selvagens", "agressivos", entre outras formas de tratamento construídas a partir das alegorias da colonização. Essas dicotomias criadas pelos interesses coloniais não representam a totalidade histórica. Viemos construindo até aqui mecanismos que possibilitem análises críticas a respeito desses documentos. As distinções mencionadas: bem e mal, bravos e mansos, heróis e vilões; são apenas representações que chegaram até nós através dos documentos. Para alguns grupos indígenas, Pires de Campos representava o mal, o "bárbaro", para outros ele seria uma espécie de líder, e assim por diante. O cerne da questão é fugirmos da história tradicional que foi escrita para pensarmos em suas mais variadas versões.
} 
substituidos pelos de brandura; seus beneficos resultados; aldeamento; conclusão. Rio de Janeiro, TOMO 24, 1973.

Revista do Instituto Histórico e Geográfico Brasileiro. Subsídios para a história da Capitania de Goiaz (1756 - 1806). Rio de Janeiro: Imprensa Nacional, Tomo 84, 1919.

Revista Trimensal de História e Geographia, ou Jornal do Instituto Histórico Geográphico Brasileiro. Notícias práticas das minas do Cuiabá e Goyazes, na Capitania de S. Paulo e Cuiabá, que dá ao Rev. Padre Diogo Soares, o Capitão João Antonio Cabral Camello, sobre a viagem que fez às Minas do Cuiabá no anno de 1727. Rio de Janeiro: Imprensa Americana de L.P. da Costa, Tomo 4, 1842.

\section{BIBLIOGRAFIA}

ALVES, Daniella Santos. Do Alto do Espia: Gentios, Calhambolas e Vadios no sertão do Campo Grande - Séculos XVIII. Dissertação (Mestrado) - Universidade Federal de Uberlândia, Programa de Pós-Graduação em Ciências Sociais, 2017.

CANCELIER DIAS, Thiago. O língua $e$ as línguas: aldeamentos e mestiçagens entre manejos de mundo indígenas em Goiás (1721-1832). Tese (Doutorado) - Universidade Federal de Goiás, Faculdade de História, Programa de Pós-Graduação em História, Goiânia, 2017.

CARNEIRO DA CUNHA, Manuela \& VIVEIROS DE CASTRO, Eduardo. Vingança e temporalidade: os Tupinambá. Journal de lasociétédesaméricanistes. LXXI, Musée L'Homme, Paris, 1985, p. 191-208.

DELEUZE, Gilles \& GUATARRI, Félix. Mil platôs: Capitalismo e esquizofrenia 2, vol.1. São Paulo: Editora 34, 2011.

FAUSTO, Carlos. Inimigos fiéis: história, guerra e xamanismo na Amazônia. São Paulo: EDUSP, 2001.

GINZBURG, Carlo. O queijo e os vermes: o cotidiano e as ideias de um moleiro perseguido pela Inquisição. São Paulo: Companhia das Letras, 2006.

GINZBURG, Carlo. Sinais: raízes de um paradigma indiciário. In: Mitos, emblemas e sinais morfologia e história. Companhia das Letras, 1989.

GIRALDIN, Odair. "Cayapó e Panará". Luta e sobrevivência de um povo Jê no Brasil Central. Campinas: Editora da UNICAMP, 1994.

GIRALDIN, Odair. "Cayapó e Panará". Luta e sobrevivência de um povo Jê no Brasil Central. Campinas: Editora da UNICAMP, 1997.

GORDON, Cesar. Economia selvagem - ritual e mercadoria entre os Xikrin-Mebêngôkre. São Paulo: ed. da UNESP/ Instituto sócio ambiental, 2006.

JUNQUEIRA, Gabriela Goncalves. O visível e o invisível nas relações de contato dos grupos Jê Meridionais: uma análise da caça, guerra e dos rituais funerários como relações de predação, produção e controle dos poderes latentes da alteridade. Dissertação (Mestrado) Universidade Federal de Uberlândia, Programa de Pós-Graduação em Ciências Sociais, 2017.

LÉVI-SRAUSS. Antropologia estrutural. Rio de Janeiro: Tempo brasileiro, 1970.

LÉVI-STRAUSS, Claude. Antropologia Estrutural dois. Tempo Brasileiro, $4^{\text {a }}$ Edição. Rio de Janeiro, 1993. 
LÉVI-STRAUSS, Claude. Tristes trópicos. São Paulo: Companhia das Letras, 1996.

MANO, Marcel. (Des)encontros culturais: um esboço parcial da história do contato dos Kayapó meridionais. In: Índios do Triângulo Mineiro: história, arqueologia, fontes e patrimônio: pesquisas e perspectivas. Aurelino José Ferreira Filho. (org). - Uberlândia: Edufu, 2015.

MANO, Marcel. Da Tradição à Cultura: problemas de investigação nos estudos das ocupações indígenas no Planalto Meridional Brasileiro. In: Patrimônio, cultura material e imaterial: diálogos e perspectivas. (orgs). Eduardo Giavara e Aurelino José Ferreira Filho. Texto enviado para publicação na Revista Albuquerque, vol. 10, n. 19, UFMS, 2018.

MANO, Marcel. Sobre as penas do gavião mítico: história e cultura entre os Kayapó. Tellus, n. 22, Campo Grande, jan-jun, 2012, p. 133-154.

MENDONÇA, José. História de Uberaba. Uberaba, Academia de Letras do Triângulo Mineiro, 1974.

MONTEIRO, John Manuel. Negros da terra: índios e bandeirantes nas origens de São Paulo. São Paulo: Companhia das Letras, 1994.

MORI, Robert. Os aldeamentos indígenas no Caminho dos Goiases: guerra e etnogênese no "sertão do Gentio Cayapó" (Sertão da Farinha Podre) - séculos XVIII e XIX. Dissertação de mestrado, 2015.

NIMUENDAJÚ, Curt. Documenta: A corrida de toras dos Timbira. Mana 7(2), p. 151-194, 2001.

RAVAGNANI, Oswaldo Martins. Aldeamentos goianos em 1750 - os jesuítas e a mineração. Revista de Antropologia. São Paulo, vol. 30/31/32, p. 111-132, 1989.

RAVAGNANI, Oswaldo Martins. Os primeiros Aldeamentos na Província de Goiás: Bororo e Kaiapó na Estrada do Anhangüera. Revista de Antropologia. São Paulo, USP, 1996, v. 39, n. 1 .

RODRIGUES, Alvaro Almeida. Da cultura da guerra a paz colonial: notícias sobre um gentio Kayapó. Dissertação (Mestrado) - Universidade Federal de Uberlândia, Programa de Pós-Graduação em Ciências Sociais, 2013.

SAHLINS, Marshall David. Ilhas de História. Rio de Janeiro: Jorge Zahar Ed., 1990.

SAHLINS, Marshall David. Metáforas históricas e realidades míticas: estrutura nos primórdios da história do reino das Ilhas Sandwich. Rio de Janeiro: Jorge Zahar Ed., 2008.

VIVEIROS DE CASTRO, E. “Os pronomes cosmológicos e o perspectivismo ameríndio”. In: Mana - Estudos de Antropologia Social, vol. 2, n. 2, out. 1996, p. 115-144.

WAGNER, Roy. A invenção da Cultura. São Paulo: Cosac Naif, 2010.

\section{SITE}

https://pib.socioambiental.org/pt/Povo:Paresí acessado em 06/06/2018 